\title{
Laying performances and egg quality of local barred hens under improved conditions in Cameroon
}

\author{
Mube H K *, Kana J R, Tadondjou C D, Yemdjie D D M, Manjeli Y and Teguia A \\ *University of Dschang, Faculty of Agronomy and Agricultural Sciences, Department of Animal Productions. PO Box: \\ 222, Dschang, Cameroon; \\ Email : mubehervemkh@yahoo.com
}

Original submitted in on $3^{\text {rd }}$ December 2014 Published online at www.m.elewa.org on $28^{\text {th }}$ February 2014.

http://dx.doi.org/10.4314/jab.v74i1.8

\begin{abstract}
Objectives: This study was designated to evaluate the laying performances and egg traits in local barred hens. Sixteen (16) hens and 4 cocks were used, divided into 4 experimental units of 4 hens and 1 cock per unit.

Methodology and Results: The following parameters were studied: feed intake ( $\mathrm{g} / \mathrm{bird} /$ day), egg production (\%/hen-day), egg weight ( $\mathrm{g}$ ), egg mass ( $\mathrm{g} / \mathrm{hen} /$ day), feed conversion ratio ( $\mathrm{g}$ feed/g egg) and egg cost (Fcfa). A total of 730 eggs were used to evaluate external egg traits including egg weight, egg length, egg width, egg index and 320 eggs to evaluate internal egg traits including relative yolk weight (\%), yolk height, yolk diameter, relative shell weight (\%), shell thickness, albumen height, relative albumen weight (\%) and haugh unit. Mean values for laying performances were: age at first egg (22.5 weeks), hen live weight at first egg (1298g), hen age at peak egg production ( 33 weeks), percent egg production at peak (57.9\%), feed conversion ratio (5.36), mean egg production $(40.4 \%)$ and egg cost $(48.5 \mathrm{Fcfa})$. Mean egg traits were: egg weight $(43.8 \mathrm{~g})$, relative albumen weight $(17.3 \%)$, albumen height $(5.74 \mathrm{~mm})$, haugh unit $(78.0)$, relative yolk weight $(34.9 \%)$, relative shell weight $(11.6 \%)$ and shell thickness $(25.9 \mathrm{~mm})$. There was a highly significant $(P<0.01)$ correlation between egg weight, yolk volume and albumen volume. This correlation was weak between egg weight and albumen height (0.060) and egg weight and shell thickness (0.020).

Conclusions and applications of findings: The present study suggests that local barred hens have a good potential for egg production, which may be useful for breed improvement, and development for future generation of local laying hens.
\end{abstract}

Key words: egg quality, laying performances, local barred hens.

\section{INTRODUCTION}

The local chicken contributes significantly to food security in poor households in most African countries (Mlozi et al., 2003; Gondwe, 2003). It is an important agricultural activity for almost all rural communities in Africa, providing animal protein in the form of meat and eggs as well as being a reliable source of petty cash, savings, investment, insurance and serves in traditional medicine (Mlozi et al., 2003). The importance of local chicken in the national economy of developing countries and its role in improving the nutritional status, income of many small-scale farmers and landless communities has been very 
significant (Mwalusanya et al., 2001; Swatson et al., 2001; Muchadeyi et al., 2007). Another merit of these chickens is their ability to scavenge for food, adapt to household leftover and use little space to rest at night. In Cameroon, the national poultry flock was estimated at 35 million, $70 \%$ being local chickens, while the $30 \%$ remaining were exotic commercial birds such as Arbor Acres, Hubbard, ISA (INS-Cameroon, 2001; Fotsa et al., 2007). In the rural area, local chicken represent about $69.4 \%$ of birds and $57 \%$ of them are being catered for by women. Moreover, the western highland is the major site for poultry production in Cameroon (MINEPIA, 2009). Keambou et al. (2007) revealed that Western Highland local chicken are made of a variety of genotype such as black chicken (17.2\%), white type $(15.3 \%)$ and barred hens (4.77\%). Village hens are characterized by slower growth rate, poor laying

\section{MATERIALS AND METHODS}

The study was carried out at the Teaching and Research Farm of the University of Dschang and lasted from 19 to 65 weeks. A total of 16 hens and 4 cocks all of barred phenotype were divided into 4 experimental units of 4 hens and 1 cock per unit, house in battery cages made of ability and smaller egg size as compared to exotic breeds (Dassie et al., 2011). However, their eggs fetch higher market prices compared to commercial layer eggs. In addition, their meat and egg taste are more preferred than that of exotic chickens (Dessie and Ogle, 2001; Issa et al., 2012). Because currently, local chicken production is increasing largely due to high demand for eggs and chicken meat, more people venture into chicken projects (Mwalusanya, 2001). Previous study on village poultry insisted on general characteristics with no particular information associated with different genotypes and egg characteristic (Fosta et al., 2007; Keambou et al., 2009). The present study was designated to characterize the egg production and egg traits of local barred chickens in order to set up a breeding program.

local bamboo. Each cage was provided with a nesting box, one automatic cup type drinker and one feeder. Throughout the experiment, the birds were fed ad libitum with commercial laying diet (Table1).

Table1: Experimental diets

\begin{tabular}{ll}
\hline Parameter & Quantity \\
\hline Crude proteins (\%) & 15.4 \\
Metabolizable Energy (kcal/kg) & 2723.9 \\
Calcium (\%) & 3.45 \\
Phosphorus (\%) & 0.69 \\
Lysine (\%) & 0.72 \\
Methionine (\%) & 0.29 \\
ME/CP & 178 \\
\hline Price* (Fcfa/kg) & $\mathbf{1 8 6}$ \\
\hline
\end{tabular}

*1 USD $=550.43 \mathrm{Fcfa}$

The following performance parameters were evaluated when layers were 19 to 65 weeks old: feed intake (g/bird/day), egg production (\%/hen-day), egg weight (g), egg mass ( $g /$ hen/day), and feed conversion ratio ( $g$ feed/g egg). Egg production was recorded daily, and the results are expressed as a percentage of the number of hen's house. Once day per week, all eggs collected were used to evaluate egg characteristics. Eggs were weighed in a $0.01-\mathrm{g}$ precision scale. Haugh units $(\mathrm{HU})$ were determined according to the equation of Nesheim et al., (1979):

$H U=100 \times \log (h+7.57-1.7 p 0.37)$

where: $h$ is albumen height $(\mathrm{mm})$ and $p$ is egg weight $(\mathrm{g})$.

Albumen height was measured at $1 \mathrm{~cm}$ from the yolk, using a $0.1-\mathrm{mm}$ precision micrometer. Yolk and albumen were separated manually, weighed and expressed as 
percentages of egg weight. Eggshells were first dried for 72 hours at room temperature, and then the thickness was measured using a $0.01-\mathrm{mm}$ precision micrometer. Mean value, maximum and minimum value, standard

\section{RESULTS}

The laying performances of local barred hens are summarized in Table 2. Hens attained sexual maturity (hen age at first lay) at an average of 156 days with an average live weight of $1186 \mathrm{~g}$. The peak egg production deviation and variation coefficient of parameter were calculated. Correlation coefficient among different egg trait was also performed. The analyses were performed using SPSS.14

was $57.9 \%$ with the average egg weight of $43.2 \mathrm{~g}$.Feed conversion ratio ranged from 2.07 to 9.61 with an average value of 5.36 .

Table2: Laying parameters of local barred hens of Cameroon Western highland.

\begin{tabular}{llllll}
\hline Factors & Minimum & Maximum & Mean & SD & CV (\%) \\
\hline Age at first egg (week) & 19 & 26 & 22.5 & 4.95 & 4.54 \\
Weight at first egg (g) & 1186 & 1410 & 1298 & 158.4 & 8.90 \\
Age at the peak (week) & & & 33 & & \\
Peak lay percent (\%) & & & 57.93 & & \\
Egg weight at peak & & & 43.2 & & \\
Cumulative Egg weight & & & 5505,45 & & \\
Egg weight & 28.0 & 53.5 & 46.8 & 4.62 & 9.86 \\
Egg/hens/day & 0.04 & 0.82 & 0.43 & 1.25 & 44.4 \\
Egg production (\%) & 3.57 & 57.9 & 40.4 & 17.7 & 43.9 \\
Feed/hens/day & 69.1 & 290.4 & 137.1 & 46.3 & 33.8 \\
Feed Conversion Ratio & 2.07 & 9.61 & 5.36 & 1.57 & 29.2 \\
Egg Price (FCFA) & 20.3 & 116.8 & 48.5 & 19.6 & 40.4 \\
& & & & & \\
\hline
\end{tabular}

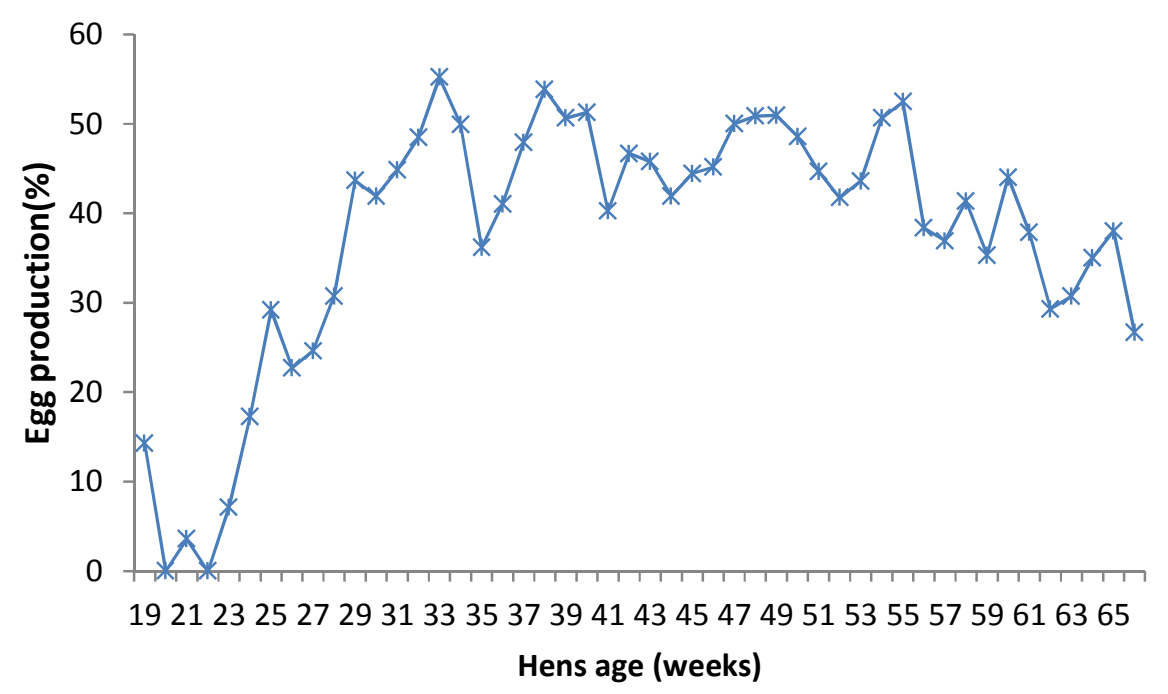

Figure 1: Local barred hens egg production (\%) 
The correlation coefficient between egg production and physical parameters were high and positive. The highest significant $(P<0.01)$ correlation $(0.850)$ was between egg weight and egg length while the lowest significant $(P<0.01)$ correlation was between shape index and egg length (Table 3).

Table 3: Correlation between egg weight and some eggs physical parameters $(\mathrm{N}=730)$

\begin{tabular}{llllll}
\hline & Number egg & Egg weight & Egg length & Egg width & Shape index \\
\hline Numberegg & 1 & & & & \\
Egg weight & 0.001 & 1 & & & \\
Egg length & -0.030 & $0.846^{* *}$ & 1 & 1 & \\
Egg width & $0.097^{* *}$ & $0.835^{* *}$ & $0.691^{* *}$ & 1 & \\
Shape index & $0.126^{* *}$ & $-0.346^{* *}$ & $-0.696^{* *}$ & 0.034 & 1 \\
\hline
\end{tabular}

${ }^{* *}$ Correlation is significant at 0.01 level.

Egg weight ranged between $35 \mathrm{~g}$ and $59 \mathrm{~g}$ (table 4). Relative albumen weight, albumen height and haugh unit ranged from 11.2 to $26.3 \%, 3.3 \mathrm{~mm}$ to $9.3 \mathrm{~mm}$ and 56.6 to 96.9 respectively. Values from the yolk relative weight, yolk height, shell relative weight and shell thickness ranged from 27.1 to $48.6,10.9 \mathrm{~mm}$ to $18.2 \mathrm{~mm}, 8.51$ to $17.7 \%$ and $10 \mathrm{~mm}$ to $37 \mathrm{~mm}$, respectively.

Table 4: Some internal egg parameter of western highland local barred hens

\begin{tabular}{lllllll}
\hline Parameter & N & Minimum & Maximum & Mean & SD & CV (\%) \\
\hline Egg weight (g) & 35 & 35.0 & 59.0 & 43.6 & 5.85 & 13.4 \\
Albumen volume (ml) & 36 & 15.0 & 29.5 & 21.4 & 2.98 & 13.9 \\
Albumen weight (g) & 36 & 15.0 & 30.0 & 23.3 & 3.32 & 14.2 \\
Albumen height (mm) & 36 & 2.90 & 17.0 & 5.74 & 2.27 & 39.5 \\
Yolkheight & 36 & 10.9 & 18.2 & 13.3 & 1.57 & 11.8 \\
Albumen diameter (mm) & 36 & 5.03 & 11 & 7.41 & 1.78 & 24.0 \\
Yolkdiameter (mm) & 36 & 3.33 & 4.40 & 3.81 & 0.27 & 7.07 \\
Yolk volume (ml) & 36 & 10.0 & 20.0 & 14.0 & 2.89 & 20.61 \\
Yolkweight (g) & 36 & 12.0 & 18.0 & 15 & 1.68 & 11.2 \\
Haugh Unit & 36 & 56.6 & 96.9 & 78.0 & 8.70 & 11.2 \\
Shell thickness (mm) & 36 & 10.0 & 37.0 & 25.9 & 6.26 & 24.1 \\
Shell weight (g) & 36 & 4.00 & 7.00 & 5.00 & 0.79 & 15.9 \\
Yolk relative weight (\%) & 36 & 27.1 & 48.6 & 34.9 & 4.11 & 11.8 \\
Albumen relative weight (\%) & 36 & 11.2 & 26.9 & 17.3 & 4.63 & 26.7 \\
Shell relative weight (\%) & 36 & 8.51 & 17.7 & 11.6 & 1.74 & 15.0 \\
\hline
\end{tabular}

The correlation between egg weight and internal egg parameter (Table 5) ranged from $-0,557$ to 0,941 . Egg weight was positively and significantly $(P<0.01)$ correlated with yolk and albumen volume. 
Table 5: Correlations between egg weight and internal egg parameter

\begin{tabular}{|c|c|c|c|c|c|c|c|c|c|c|}
\hline EW & $\begin{array}{l}\text { EW } \\
1\end{array}$ & RAW & RYW & RSW & ST & YV & AV & $\mathrm{YH}$ & $\mathrm{AH}$ & $\mathrm{HU}$ \\
\hline RAW & $-0.379^{*}$ & 1 & & & & & & & & \\
\hline RYW & $-0.557^{* *}$ & 0.084 & 1 & & & & & & & \\
\hline RSW & -0.368 & $0.395^{*}$ & 0.259 & 1 & & & & & & \\
\hline ST & 0.002 & 0.111 & 0.183 & 0.022 & 1 & & & & & \\
\hline YV & $0.749^{* *}$ & -0.271 & -0.051 & -0.163 & -0.013 & 1 & & & & \\
\hline AV & $0.705^{\star *}$ & $-0.518^{* *}$ & $-0.408^{*}$ & $-0.50^{* *}$ & -0.229 & $.389^{\star}$ & 1 & & & \\
\hline YH & -0.039 & 0.077 & 0.281 & 0.111 & -0.181 & 0.256 & -0.109 & 1 & & \\
\hline $\mathrm{AH}$ & 0.061 & $-0.438^{* *}$ & 0.288 & -0.263 & 0.077 & 0.272 & 0.087 & -0.012 & 1 & \\
\hline HU & -0.252 & -0.323 & $.459^{\star *}$ & -0.120 & 0.116 & 0.03 & -0.152 & -0.001 & $0.941^{* *}$ & 1 \\
\hline
\end{tabular}

${ }^{*}$ Correlation is significant at the 0.05 level (2-tailed); ${ }^{*}$ Correlation is significant at the 0.01 level (2-tailed). (EW=egg weight; R AW= albumen weight (\%); RYW = yolk weight (\%); RSW = Shell Weight (\%); ST= Shell Thickness $\mathrm{YV}=$ yolk volume; $\mathrm{AV}=$ albumen volume; $\mathrm{YH}=$ yolk height; $\mathrm{AH}=$ albumen height; $\mathrm{HU}=$ Haugh Unit).

\section{DISCUSSION}

The age at first eggs ( 133 and 182 days) is in the average range reported by Akouango et al. (2010), Fosta et Manjeli, 2010 and Kreman, 2012. The minor differences observed are probably due to the conjugated effect of genetic diversities, environments, and the rearing conditions of different local hens use by these authors. In the present study, the hen's body weight at first lay range between 1186 to $1410 \mathrm{~g}$. This result is in close agreement with the report of Yapi-gnaore et al. (2009) and Kreman (2012) respectively in Ivory Coast $(1173.9 \mathrm{~g})$ and Cameroon (1195.6 g). The body weight of the scavenging hen at first egg in the savanna region of Cameroon $(1365.5 \mathrm{~g})$ was higher than that observed in the present study (Fosta et al., 2007). The difference can be attributed to genetic variability, environment and rearing conditions. The results on egg weight, egg mass, feed/hens/day, egg production and egg prices in this study were very close to the results reported by Tchoumboué et al. (2000), Keambou et al. (2007) on some village chickens in Western Highland Cameroon. Except egg weight, all other laying performances in this study were lower than that reported by Kreman (2012). This could be attributed to the fact that our birds were chicks from the parent used by Kreman. However, the large variation within different egg trait suggests a wide individual variation as may be expected in an unselected flock (Fayeye et al., 2005). This study recorded a high correlation between egg length and egg width and weak correlations with shape index similar to the findings by Anderson et al., (2004) and Abanikannda and Leigh, (2012). These high correlations values provide an indicator for better prediction of egg weights. There was significant correlation between egg weight and albumen relative weight, egg weight and yolk relative weight, egg weight, albumen and yolk volume. The present findings on local barred hens agreed with Isa Brown layers (Adedeji et al., 2008; Olawumi and Ogunlade, 2009) and the local chickens in Nigeria (Momohet al 2010.). Furthermore, the negative correlation values between egg weight and shape index as well as relative yolk weight and relative albumen weight agreed with Pohle and Cheng (2009) and Momohet al., (2010), but disagreed with Olawumi and Ogunlade (2009) who obtained significant positive correlation between yolk weight and albumen ratio. The mean egg weight, albumen weight, yolk weight, shell thickness and haugh unit in this work were slightly higher than values obtained by Fayeye et al., (2005) on Fulani-ecotype chickens in Nigeria. Egg weights in the present study were lower than the values reported by Oguike and Onykweodiri (1999) for commercial exotic layer strains. This variation could be associated with genotypes. Mean shell weight obtained in this study was similar to the $5.04 \mathrm{~g}$ of Fulani-ecotype chickens reported by Fayeye et al., (2005). This is an indicator of good shell thickness, which may help to reduce the percentage of cracked eggs. The high haugh units (78) in the present study suggest that eggs from local barred chickens are highly desirable since this indice is the best indicator of internal egg quality (Isikwenu et al., 1999). In addition, the higher the yolk weight and haugh unit the more desirable the egg quality (Ayorinde, 1987). According to lhekoronye and Ngoddy (1985) high quality egg generally have haugh unit of 70 and above. 


\section{Mube et al. J. Appl. Biosci. 2014. Laying performances and egg quality of local barred hens under}

improved conditions in Cameroon

\section{CONCLUSION}

It can be concluded from the present work that local barred hens is a good reservoir of egg quality that may be tapped in commercial production. The wide individual

\section{REFERENCES}

Abanikannda OTF and Leigh AO, 2012.Grading of table eggs as a marketing strategy for Nigerian smallholder farmers International Journal of Livestock Production Vol. 3(4), pp.43-46, April 2012 DOI:10.5897/IJLP11.038. ISSN 2141-2448 (C2012 Academic Journals

Adedeji TA, Ojedapo AO, Ige SA, Akinwunmi AO, Amao SR, 2008 Genetic evaluation of growth performance of pure and crossbred chicken progenies in a derived savannah environment. Proc. of the $13^{\text {th }}$ Annual Conference of the Animal Science Association of Nigeria, (ASAN), Sept. 15 -19.ABU Zaria: 8-12

Akouango F, Bandtaba P, Ngokaka C, 2010.Croissance pondérale et productivité de la poule locale Gallus domesticus en élevage fermier au Congo. Animal Genetic Resources, 46: 61-65

Anderson KE, Tharington JB, Curtis PA, Jones FT, 2004. International journal of poultry science, 3: 17-19

Ayorinde KL, 1987.Physical and chemical characteristics of the eggs of four indigenous guinea fowls in Nigeria. Nigeria Journal of Animal Production. Volume14: 125-128

Dessie T. and Ogle B, 2001. Village poultry production systems in the Central Highlands of Ethiopia. Tropical Animal Health and Production, 33: 521 537

Dessie T, Taye T, Dana N, Ayalew W, Hanotte O, 2011.Current state of knowledge on phenotypic characteristics of indigenous chickens in the tropics. World's Poultry Science Journal, 67: 507-516

Ekue FN, Pone KD, Mafeni MJ, Nfi AN, Njoya J, 2002. Survey of the traditional poultry production system in the Bamenda area, Cameroon. In Characteristics and Parameters of Family Poultry Production in Africa. FAO/IAEA Coordinated Research Programme on Assessment of the effectiveness of vaccination strategies against Newcastle disease and Gumboro disease using immunoassay-based technologies for increasing farmyard poultry production in Africa.

IAEA variation for these traits also suggests that fast genetic progress could be made through individual selection among the local barred hens.

Vienna.http://www.iaea.or.at/programmes/nafa/d 3/public/2-survey-ekue.pdf

Fayeye TR, Adeshiyan AB, Olugbami AA, 2005.Egg traits, hatchability and early growth performance of the Fulani-ecotype chicken.Livestock Research for Rural Development. Volume 17, Article \# 8 Retrieved June 25, 2010, from http://www.Irrd.org//rrd17/8/faye17094.htm

Fotsa J-C, 2008. Caractérisation des populations de poules locales (Ggallus gallus) au Cameroun. Thèse de doctorat, Agroparistech, Paris, 301 pp.

Fotsa JC et Manjeli Y, 2010.Caractérisation phénotypique des populations de poules locales (Gallus Gallus) de la zone forestière dense humide à pluviométrie bimodale du Cameroun. Annales des Sciences Agronomiques $d u$ Bénin.2(2) : 181-192

Fotsa JC, Poné Kamdem D, Manjeli Y, Ngou Ngoupayou JD, 2007.The State of Cameroon Rural Chickens: Production and Development Perspectives for Poverty Alleviation. Ghanaian Journal of Animal Science, Vol 2\&3, 1, 175-180

Gondwe TNP, Wollny CBA, Safalaoh ACL, Chilera F and Chagunda MGG, 2003. Community - based promotion of rural poultry diversity, management, utilization and research in Malawi. In: FAO Community - Based Management of Animal Genetic Resources. Proceedings of the workshop held in Mbabane, Swaziland, 7 - 11 May 2001. pp. 69 - 76

Ihekoronye AT and Ngoddy PO, 1985.Integrated food science technology for the tropics. Macmillan press Ltd. London.

INS-Cameroun, 2001. Institut National des Statistiques: Note annuelle sur le secteur primaire. Agriculture, Elevage, pêche.Pp 30

Isikwenu JO, Okaplefe CS, Mmereole FUC, 1999. Storability of chicken eggs under different storage conditions. Proceedings of the 26th Annual Nigeria Society for Animal Production Conference, 21-25 March 1999, llorin

Issa Y, Mopate LY, Missohou A, 2012. Commercialisation et consommation de la volaille traditionnelle en Afrique subsaharienne. 


\section{Mube et al. J. Appl. Biosci. 2014. Laying performances and egg quality of local barred hens under}

improved conditions in Cameroon

Journal of Animal \& Plant Sciences, Vol. 14, Issue $\quad 3$ : 1985-1995, http://www.m.elewa.org/JAPS; ISSN 2071 7024

Keambou TC, Boukila B, Moussonda G, Manjeli Y, 2009. Comparaison de la qualité des œufs et des performances de croissance des poussins locaux des zones urbaines et rurales de l'OuestCameroun. International Journal of Biological and Chemical Sciences, 3, (3)

Keambou TC, Manjeli Y, Téguia A, Tchoumboué J, Iroumé RN, 2007.Détermination du poids par des mensurations corporelles chez la poule locale des hautes terres de l'ouest Cameroun. Biosciences Proceedings, Vol. 11: 156-165

Kreman, 2012. Effet du taux d'incorporation de la farine de manioc dans l'aliment sur les performances de croissance et de ponte de la poule villageoise. Thèse de Master en Biotechnologie et Production Animales de la FASA, Université de Dschang. 45-60p

MINEPIA ,2009.Ministère de l'élevage, des pêches et des industries animales, schéma directeur pour le développement des filières de l'élevage au Cameroun. Vol, 2. Cartographie des filières. 82pp.

Mlozi MRS, Kakengi AVM, Minga UM, Mtambo AM, Olsen JE, 2003.Marketing of free - range local chickens in Morogoro and Kilosa urban markets, Tanzania. Livestock Research for Rural Development, $\quad$ 15, 2:2003 http://www.cipav.org.co//rrd//rrd15/2/mloz152.ht $\underline{m}$

Momoh OM, Ani AO, Ugwuowo LC, 2010. Part-period egg production and egg quality characteristics of two ecotypes of Nigerian local chickens and their F1crosses. International Journal of Poultry Science, 9(8), 744-748

Mtileni BJ, Muchadeyi FC, Maiwashe A, Phitsane PM, Halimani TE, Chimonyo M,Dzam K,2009. Characterization of production systems for indigenous chicken genetic resources of South Africa. Applied Animal Husbandry \& Rural Development 2009, Volume 2, 18-22: www.sasas.co.za/aahrd/

Muchadeyi FC, Sibanda S, Kusina NT, Kusina J, Makuza SM, 2005. Village chicken flock dynamics and the contribution of chickens to household livelihoods in a smallholder farming area in
Zimbabwe. Trop. Anim. Health Prod. 37, 333344

Muchadeyi FC, Wollny CBA, Eding H, Weigend S, Makuza SM, Simianer $H$, 2007. Variation in village chicken production systems among agroecological zones of Zimbabwe. Tropical Animal Health and Production. 39, 453-461

Mwalusanya NA, Katule AM, Mutayoba SK, Mtambo MMA, Olsen JE, Minga UM, 2001. Productivity of local chickens under village management conditions. Tropical Animal Health and Production, 34 (5): 405 - 416

Nesheim MC, Austic RE, Card LE, 1979. Poultry production. 12th ed. Philadelphia

Oguike MA and Onyekweodiri EO, 1999. Eggshell quality of four commercial strains of layers. Proceedings of the 26th Annual NSAP Conference, 21-25 March 1999, Ilorin

Olawumi SO and Ogunlade JT, 2009. The effects of genotype and Age of layer Breeders on Egg quality Traits. Nig. Journal of Animal Production, 36 (2): 228- 236

Pohle $\mathrm{K}$ and Cheng HW, 2009. Comparative effects of furnished and battery cages on egg production and physiological parameters in White Leghorn hens. Poultry Science. $\mathrm{N}^{\circ} 88 \mathrm{Vol}(10): 2042-51$. doi : 10.3382/ps.2009-00171. Région de Dakar (Sénégal). Thèse: Méd. Vét: Dakar; 36

Swatson HK, Nsahlai IV, Byebwa B, 2001. The status of smallholder poultry production in the Alfred District of Kwazulu-Natal, South Africa: priorities for intervention. Livestock Community and Environment. Proceedings of the 10th Conference of the Association of Institutions for Tropical Veterinary Medicine, Copenhagen, Denmark

Teno G, 2009.Étude des déterminants de la consommation du poulet du pays : Cas de la région de Dakar (Sénégal).Thèse : Méd. Vét : Dakar ; $36 \mathrm{Pp}$

Tharrington JB, Curtis PA, Jones FT, Anderson KE, 1999. Comparison of Physical

Yapi-gnaoré CV, Loukou NE, Konan JCB, Touré G, Kreman K, Youssao I, Kayang B, Rognon $\mathrm{X}$,Tixier BM, 2009.Evolution du poids vif et paramètres de la courbe de croissance des poulets de race locale (Gallus domesticus) de Côte d'Ivoire. Journal of Animal and Plant Science, 5 (1) : 425 - 436. 